Journal of Clinical Investigation

Journal of Clinical In
Vol. 41, No. 7,1962

\title{
MECHANISMS OF IMPAIRED WATER EXCRETION IN ADRENAL AND PITUITARY INSUFFICIENCY. III. THE EFFECT OF EXTRACELLULAR OR PLASMA VOLUME EXPANSION, OR BOTH, ON THE IMPAIRED DIURESIS *
}

\author{
By RALPH E. CUTLER, $†$ CHARLES R. KLEEMAN, JERRY KOPLOWITZ, \\ MORTON H. MAXWELL AND J. THOMAS DOWLING
}

\author{
(From Wadsworth Hospital, Veterans Administration Center, the Department of Medicine, \\ University of California Medical Center; and the Division of Medicine, \\ Mount Sinai Hospital, Los Angeles, Calif.)
}

(Submitted for publication October 26, 1961 ; accepted March 15, 1962)

Earlier studies suggest that cortisol and related glucocorticoids correct the impaired water diuresis of primary and secondary adrenal insufficiency by a direct effect upon the diluting segment of the nephron (1-4); however, no one has conclusively demonstrated that a sustained positive water balance in the adrenal-insufficient patient completely inhibits the secretion of antidiuretic hormone $(\mathrm{ADH})$. Although osmotic inhibition of the release of $\mathrm{ADH}$ may be normal in adrenal insufficiency, the human or animal in this state may have a distorted "volume" stimulus that prevents complete inhibition. Recent studies have demonstrated that contraction or redistribution of both vascular and extracellular volumes can cause the continued secretion of $\mathrm{ADH}$ in the water-loaded subject (5, $6)$. Blood loss, quiet standing, venous congestion of the lower extremities, and positive pressure breathing are all events that may produce this contraction or redistribution.

Since the adrenal-insufficient patient is hypotensive. has poor vascular reactivity, and exhibits a redistribution of body fluids (7-9), it seems reasonable to assume that a distorted volume stimulus for release of $\mathrm{ADH}$ might contribute to his impaired water diuresis. If this were true, it might be possible to improve the water diuresis by an appropriate expansion of either the extracellular or vascular compartment before or during a water load. This was attempted in the present study. It was found that the correction of the

* This investigation was supported in part by Public Health Service Grant A-2972 from the Institute of Arthritis and Metabolic Diseases and a grant from the Upjohn Company, Kalamazoo, Mich.

† United States Public Health Service Postdoctoral Research Fellow in Metabolism, Wadsworth Hospital, Los Angeles, Calif. impaired water diuresis caused by an acute injection of glucocorticoid could not be reproduced by volume expansion. Therefore, it is unlikely that cortisol augments the water diuresis of adrenal insufficiency by correcting an abnormal "volume" stimulus to $\mathrm{ADH}$ release.

\section{METHODS}

Subjects. Four patients with primary adrenal insufficiency and nine with well documented adrenal insufficiency secondary to anterior pituitary disease comprised the study groups. These are summarized in the Appendix. Four male subjects of comparable age, without cardiovascular, renal, or endocrine disease, served as controls.

Procedure. All therapy with adrenal steroids was discontinued 1 to 2 weeks before the acute experiments in every adrenal-insufficient subject. Each experiment was performed during a maximal water diuresis sustained for 5 to 9 hours. The technique of achieving and maintaining the diuresis was accomplished as follows. On the morning of the test the fasting subjects came to the laboratory, and the experiment began about 8:30. The recumbent position was maintained throughout the test except for brief periods of standing to void. The diuresis was initiated with an oral water load of 1 to $1.5 \mathrm{~L}$ (20 $\mathrm{ml}$ per $\mathrm{kg}$ ) and this positive balance was maintained for the duration of the experiment by the intravenous infusion of 2.5 per cent glucose in water at a rate equal to urine flow. Collection periods were 20 to 60 minutes in duration, and urine samples were collected by spontaneous voiding or by indwelling catheters. When urine volume was below $2 \mathrm{ml}$ per minute, air "washouts" were also utilized. Samples of venous blood were obtained at the midpoint of each period through an indwelling needle. Control collections were begun approximately 45 minutes after a priming dose and constant sustaining infusion of inulin had been started. Analysis of plasma and urine for sodium, potassium, inulin, creatinine, and osmolality were made by methods previously reported $(1,10)$.

Volume expansion with albumin was accomplished as follows. Subjects 6,7 , and 8 received $600 \mathrm{ml}$ : Subjects 9 and 16, and two control subjects received $1 \mathrm{~L}$ of 
5 per cent albumin in 0.9 per cent saline; Patient 1 was given $50 \mathrm{~g}$ of concentrated serum albumin ( 25 per cent) intravenously over a 1 -hour period after a maximal sustained water diuresis had been achieved.

The effects of volume expansion on the impaired water diuresis were compared in the same subject with the effects of acute intravenous glucocorticoid administration ( $20 \mathrm{mg}$ of methylprednisolone or $100 \mathrm{mg}$ of cortisol). In most experiments the steroid was given on the day of volume expansion 2 to 3 hours after expansion had produced its maximal effects. In Subjects 2, 3, and 13 the effects of volume expansion alone were observed over a 4- to 6-hour period, and the results were compared with those of steroid administration during a sustained water load on another day. The sustained water diuresis was continued for approximately 4 hours after steroid administration in all experiments.

In three normal subjects (nos. 14-16) volume expansion plus steroid infusion was compared with volume expansion alone. The methodology of expansion and steroid administration were similar to those in the adrenalinsufficient patients. In the remaining normal subject (no. 17) the effects of steroid administration combined with expansion were compared with the maximal effects of volume expansion alone, achieved earlier the same day. These four experiments were done to determine whether acute administration of glucocorticoid to the "expanded" normal subject could augment the water diuresis.

TABLE I

Comparison of the effect of saline and albumin loading with adrenal steroid on the impaired water diuresis of adrenal and pituitary insufficiency

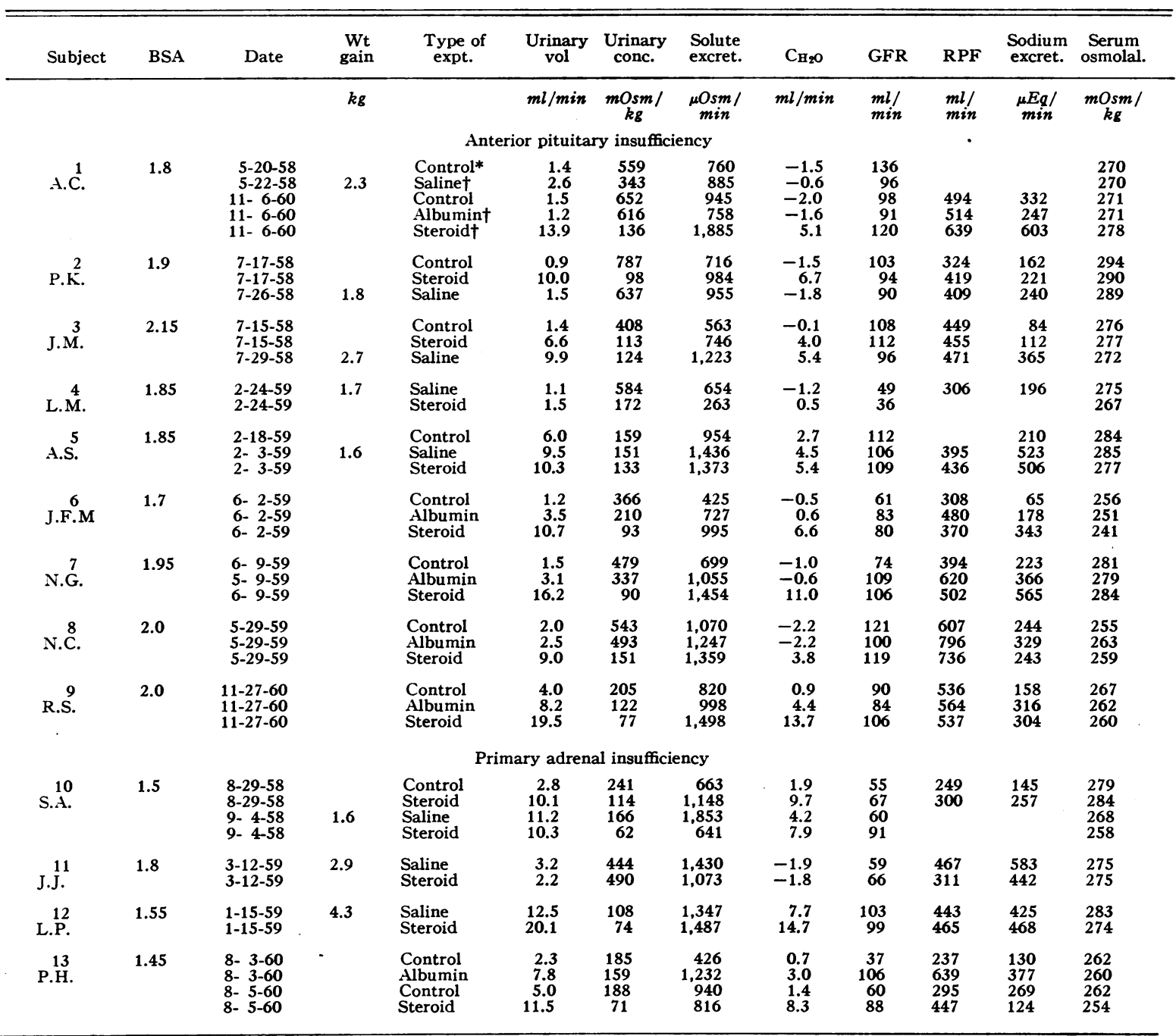

* Represents the mean of two control periods prior to volume expansion or steroid administration.

† Represents the period of maximal change after volume expansion, or steroid administration, or both (see text). 

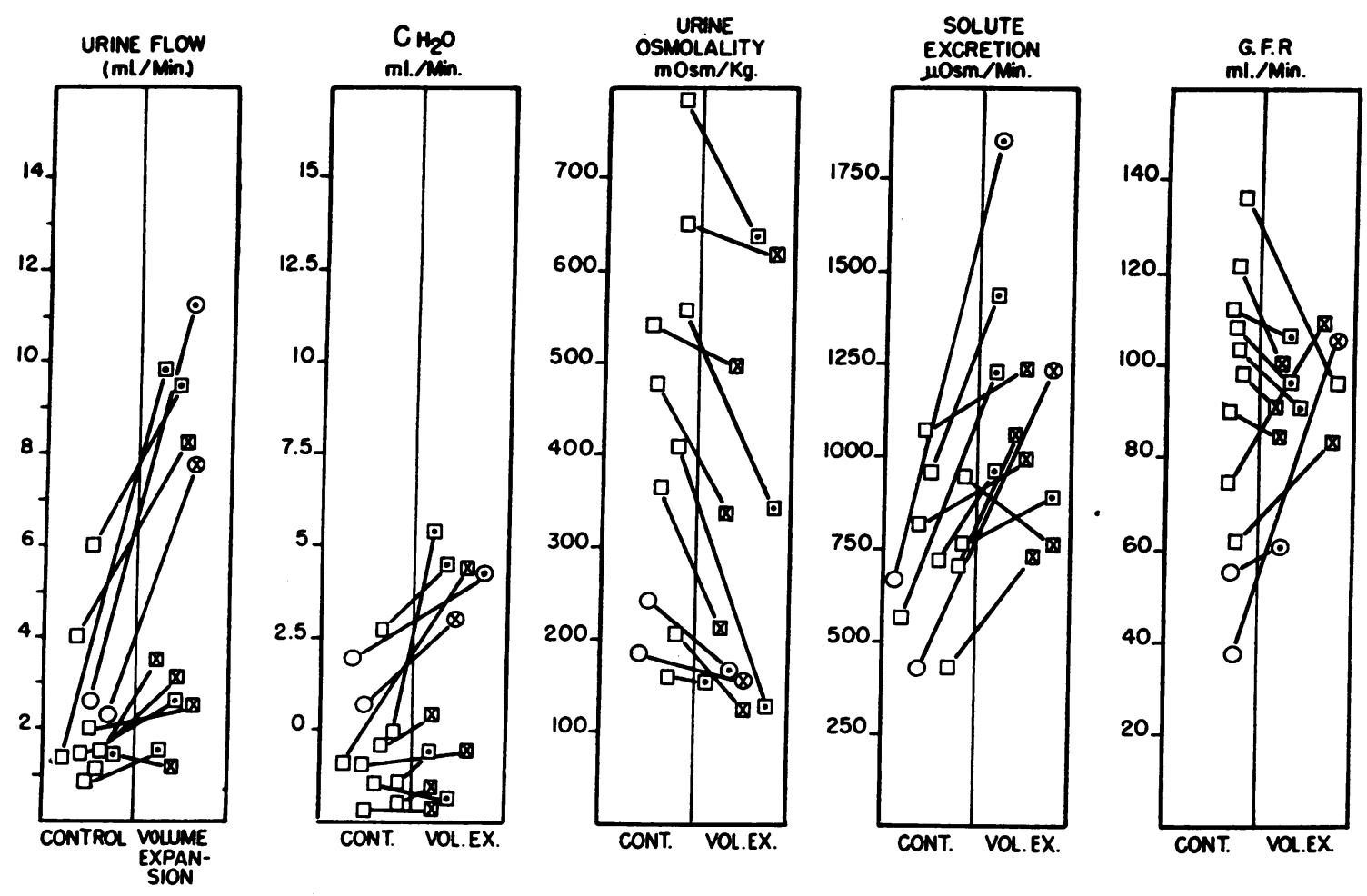

D ANT. PIT. INSUFFICIENCY

- saline eXPANSION

O PRIM. ADR. INSUFFICIENCY

$X$ ALBUMIN EXPANSION

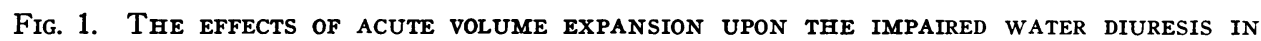
ADRENAL AND PITUITARY INSUFFICIENCY.

\section{RESULTS}

A) Characteristics of the water diuresis and renal hemodynamics prior to volume expansion or steroid administration. Water diuresis was markedly impaired in nine of the ten adrenalinsufficient subjects in whom control data were obtained. The remaining subject (no. 5) showed impaired diuresis when compared with normal subjects or with the magnitude of his diuresis after acute or chronic glucocorticoid therapy. The mild impairment in the untreated state is consistent with his clinical, partial secondary adrenal insufficiency.

Despite the lack of comparable control data in the other three patients in this study (nos. 4, 11, 12), the poor diuresis noted in Patients 4 and 11 after volume expansion and acute steroid infusion strongly suggests that their pretreatment water diuresis would also have been seriously impaired.

In the two subjects with primary adrenal insufficiency, for whom control data were available, a mean maximal water diuresis of $2.6 \mathrm{ml}$ per minute and a minimal urinary osmolality of $213 \mathrm{mOsm}$ per $\mathrm{kg}$ were achieved. This result is similar to the results in comparable subjects in a previous study (1). Although those with secondary adrenal insufficiency were able to excrete water at a comparable rate $(2.1 \mathrm{ml}$ per minute), they achieved a minimal urinary osmolality of only $462 \mathrm{mOsm}$ per $\mathrm{kg}$. As in the previous study, the defective urinary dilution thus appeared to be more severe in individuals with pituitary disease (1).

Clearances of inulin (GFR) and sodium paraminohippurate (RPF), when corrected to a surface area of $1.73 \mathrm{~m}^{2}$, were reduced in all but Subjects 5 and 8, a finding characteristic of untreated patients with primary and secondary adrenal insufficiency (11).

$B$ ) Effect on the impaired diuresis of expansion of either the plasma or total extracellular volume. The total extracellular volume was expanded by infusing isotonic saline, while expansion of the plasma compartment was achieved by infusing 
isoncotic albumin. In Subject 1 hyperoncotic albumin was given so that plasma expansion was achieved at the expense of some decrease in the volume of interstitial fluid.

Although plasma or extracellular volumes were not directly measured, it seems reasonable to conclude that the desired expansion was achieved, since appreciable weight gain occurred after saline loading, and hemodilution was noted after infusion of albumin.

Inspection of the data (Table I and Figure 1) reveals that volume expansion by either technique is accompanied by an increase in the rate of urinary flow, solute excretion, and free water clearance $\left(\mathrm{C}_{\mathrm{H}_{2} \mathrm{O}}\right)$. The mean increments above control rates were $3.3 \mathrm{ml}, 393 \mu \mathrm{Osm}$, and $1.6 \mathrm{ml}$ per minute, respectively.

When measured, it was noted that the level of RPF was augmented above the control value by volume expansion. The effect on GFR was variable, with only four patients (nos. $6,7,10,13$ ) showing an increase, and only two of these (Patients 10,13) were among those who had a distinct augmentation in diuresis with volume expansion. It is evident, therefore, that an improvement in diuresis can occur without an increase in GFR, and RPF can increase without any improvement in diuresis.

Finally, it is noteworthy that despite some increase in the parameters of water diuresis in almost every subject, only half of the patients (nos. $3,5,9-11,13$ ) showed an improvement that was large enough to call significant. The reason for the augmented diuresis in these patients, in contrast to the other five, is probably related to their greater solute excretion after volume expansion (except no. 9).

C) The effect of acute administration of glucocorticoids on the impaired diuresis. After infusion of the glucocorticoid there was an improvement in the diuresis in all but Subjects 4 and 11. The mean increments in urinary flow and $\mathrm{C}_{\mathrm{H}_{2} \mathrm{O}}$ were 5.1 and $5.2 \mathrm{ml}$ per minute, respectively, despite a mean decrement in solute excretion of $26 \mu \mathrm{Osm}$ per minute. This improvement is likewise demonstrable in the greater maximal urinary dilution (lower urinary osmolality) in almost ever patient.

It cannot be inferred, however, from this overall decrease in "mean" solute excretion after glucocorticoid treatment that the augmented diuresis in most subjects was entirely independent of an increase in solute excretion, or renal hemodynamics, or both. With the exception of Subjects 2, 12 , and 13 , whenever steroids augmented the diuresis significantly over that produced by volume expansion, there was some increase in solute excretion or GFR, or both. Subjects who showed a lower solute excretion (nos. 3-5, 10, 11) either did not show a significantly augmented diuresis over volume expansion (nos. $3,4,11$ ) or there was a counterbalancing rise in GFR (nos. 5, 10).

$D$ ) The effect of acute administration of glucocorticoids after volume expansion in normal subjects. Although the acute infusion of glucocorticoids in normal subjects during a sustained maximal water diuresis does not enhance the parameters of that diuresis $(2,11,12)$, there was the possibility that prior volume expansion might alter this relationship. Data obtained during studies of four normal subjects who were given corti-

TABLE II

Comparison of the effect of saline and albumin loading with adrenal steroid on the water diuresis in normal subjects

\begin{tabular}{|c|c|c|c|c|c|c|c|c|c|c|c|c|}
\hline Subject & BSA & Date & $\underset{\text { gain }}{W t}$ & $\begin{array}{c}\text { Type of } \\
\text { expt. }\end{array}$ & $\begin{array}{l}\text { Urinary } \\
\text { vol }\end{array}$ & $\begin{array}{l}\text { Urinary } \\
\text { conc. }\end{array}$ & $\begin{array}{l}\text { Solute } \\
\text { Excret. }\end{array}$ & $\mathrm{C}_{\mathrm{H}_{2} \mathrm{O}}$ & GFR & RPF & $\begin{array}{c}\text { Sodium } \\
\text { excret. }\end{array}$ & $\begin{array}{c}\text { Serum } \\
\text { osmolal. }\end{array}$ \\
\hline & & & $\mathrm{kg}$ & & $m l / m i n$ & $\underset{k g}{m O s m} /$ & $\underset{\min }{\mu O s m /}$ & $m l / m i n$ & 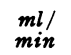 & $m l / m i n$ & $\underset{\min }{\mu E q /}$ & $\underset{k g}{m O s m / ~}$ \\
\hline $\begin{array}{c}14 \\
\text { J.B. }\end{array}$ & 1.75 & $\begin{array}{l}11-4-60 \\
11-9-60\end{array}$ & $\begin{array}{l}3.3 \\
3.2\end{array}$ & $\begin{array}{l}\text { Steroid* } \\
\text { Saline† }\end{array}$ & $\begin{array}{l}25.9 \\
25.3\end{array}$ & $\begin{array}{l}81 \\
79\end{array}$ & $\begin{array}{l}2,096 \\
1,997\end{array}$ & $\begin{array}{l}18.4 \\
19.1\end{array}$ & $\begin{array}{l}172 \\
134\end{array}$ & $\begin{array}{l}607 \\
724\end{array}$ & $\begin{array}{l}603 \\
680\end{array}$ & $\begin{array}{l}280 \\
278\end{array}$ \\
\hline $\begin{array}{c}15 \\
\text { G.M }\end{array}$ & 1.7 & $\begin{array}{l}2-25-61 \\
2-28-61\end{array}$ & $\begin{array}{l}1.1 \\
1.8\end{array}$ & $\begin{array}{l}\text { Steroid } \\
\text { Saline }\end{array}$ & $\begin{array}{l}32.2 \\
32.1\end{array}$ & $\begin{array}{l}88 \\
72\end{array}$ & $\begin{array}{l}2,834 \\
2,311\end{array}$ & $\begin{array}{l}21.9 \\
23.4\end{array}$ & $\begin{array}{l}193 \\
166\end{array}$ & $\begin{array}{r}840 \\
1,086\end{array}$ & $\begin{array}{l}667 \\
770\end{array}$ & $\begin{array}{l}274 \\
267\end{array}$ \\
\hline $\begin{array}{r}16 \\
\text { L.S. }\end{array}$ & 1.85 & $\begin{array}{l}11-17-60 \\
11-15-60\end{array}$ & & $\begin{array}{l}\text { Steroid } \\
\text { Albumin }\end{array}$ & $\begin{array}{l}12.9 \\
13.4\end{array}$ & $\begin{array}{l}95 \\
85\end{array}$ & $\begin{array}{l}1,227 \\
1,142\end{array}$ & $\begin{array}{l}8.7 \\
9.5\end{array}$ & $\begin{array}{l}97 \\
94\end{array}$ & $\begin{array}{l}550 \\
509\end{array}$ & $\begin{array}{r}76 \\
274\end{array}$ & $\begin{array}{l}289 \\
291\end{array}$ \\
\hline $\begin{array}{l}17 \\
\text { J.M }\end{array}$ & 1.88 & $\begin{array}{l}2-24-61 \\
2-24-61\end{array}$ & & $\begin{array}{l}\text { Albumin } \\
\text { Steroid }\end{array}$ & $\begin{array}{l}30.0 \\
28.8\end{array}$ & $\begin{array}{l}61 \\
62\end{array}$ & $\begin{array}{l}1,860 \\
1,783\end{array}$ & $\begin{array}{l}23.4 \\
22.5\end{array}$ & $\begin{array}{l}144 \\
143\end{array}$ & $\begin{array}{r}1,040 \\
903\end{array}$ & $\begin{array}{l}336 \\
378\end{array}$ & $\begin{array}{l}280 \\
285\end{array}$ \\
\hline
\end{tabular}

* Represents the period of maximal diuresis after volume expansion plus steroid administration. 
sol after volume expansion, in the same manner as the foregoing subjects, are contrasted with those obtained after volume expansion alone (Table II). Although GFR and solute excretion are increased after glucocorticoid administration in the subjects expanded with saline, there was no enhancement of the parameters of a water diuresis in any subject.

\section{DISCUSSION}

In the current study the impaired water diuresis of adrenal and pituitary insufficiency could only partially be corrected with saline or albumin infusions. In all but Subject 9 this correction could be explained by the augmentation of renal hemodynamics or solute excretion. Likewise, the further improvement of the impaired diuresis after adrenal steroid administration was usually associated with changes in solute excretion or renal hemodynamics, or both, so that a separate effect of glucocorticoids independent of those parameters could not be demonstrated in most cases. It seems unlikely, however, that the improvement in diuresis in many subjects after adrenal steroids was due to changes in solute excretion or renal hemodynamics alone, or both, since similar or greater increases in these parameters have been observed in comparable subjects after aminophylline or mercurials but without so marked a correction of the diuresis (1). Furthermore, in Subjects 2 and 12 adrenal steroids produced an effect on the water diuresis which was far greater than that produced by volume expansion, although the changes induced in solute excretion and renal hemodynamics were comparable. A possible synergistic effect of glucocorticoids and volume expansion is improbable in the light of the negative results seen with normal subjects which, in turn, is consistent with the results in nonexpanded subjects $(2,12)$.

If an "aberrant" volume stimulus to ADH release contributes significantly to the impaired water diuresis in adrenal insufficiency, it was not correctable by the technique of volume expansion utilized in this study. The findings suggest that the defective water diuresis is not due to a continued nonosmotic stimulus for ADH release but do not, however, entirely obviate that possibility $(10,13-16)$.

It might be postulated that the administration of glucocorticoids allows a normal inhibition of $\mathrm{ADH}$ release during water loading and that this is the significant mechanism by which the impaired water diuresis is corrected. This possibility seems unlikely in view of the following:1) the inability of alcohol, a powerful inhibitor of the neurohypophyseal system, to cause a normal diuresis in the adrenal-insufficient patient $(17) ; 2)$ the acute administration of glucocorticoids improves the water diuresis of patients with combined anterior and posterior pituitary insufficiency (9); and 3) intracarotid perfusion of the supraoptico-neurohypophyseal system with physiologic amounts of cortisol does not enhance diuresis in the waterloaded, adrenal-insufficient dog (18). The possibility that the renal tubule is oversensitive to $\mathrm{ADH}$ or that there is some impairment in the metabolic degradation of ADH in adrenal insufficiency seems adequately disproved by previous work (12). It thus seems most likely that glucocorticoids improve the impaired diuresis by a direct effect upon the diluting segment of the nephron. The augmented water diuresis noted after chronic administration of glucocorticoid in subjects with vasopressin-sensitive and vasopressin-resistant diabetes insipidus $(12,19)$, as well as the findings of the current study, continue to support this concept.

\section{SUM MARY}

1. The effects of saline or albumin infusions on the impaired water diuresis of 13 subjects with pituitary or adrenal insufficiency were compared with the effects of steroid administration.

2. The moderate improvement of the impaired diuresis caused by volume expansion was probably due to the concomitant increase in renal hemodynamics, or solute excretion, or both.

3 . The greater improvement in the diuresis that followed glucocorticoid administration was probably due to a primary and direct effect on the renal tubule, as well as a concomitant increase in renal hemodynamics, or solute excretion, or both.

4. The results suggest that the impaired excretion of water in primary and secondary adrenal insufficiency is not caused by an "aberrant volume stimulus" to the release of ADH.

\section{ACKNOWLEDGMENT}

The authors gratefully acknowledge the technical assistance of Miss Rose Twiss and Miss Emma Radler, and 
the secretarial assistance of Miss Bernice Hodgin and Mrs. Norma Pearce.

\section{APPENDIX}

Summary of cases in Table I (all males)

1. Age, 35. Mixed eosinophilic and chromophobe adenoma with gonadal, thyroidal, and adrenal insufficiency secondary to hypophysectomy 1 year prior to studies. Therapy: depotestosterone and desiccated thyroid. No adrenal replacement for 2 weeks before study.

2. Age, 38. Chromophobe adenoma surgically removed 10 years before study. Gonadal, thyroidal, and adrenal insufficiency. Therapy: testosterone and desiccated thyroid. No adrenal replacement for 1 month before study.

3. Age, 60. Chromophobe adenoma surgically removed 20 years before study. Gonadal, thyroidal, and adrenal insufficiency of 6 to 8 years' duration. No adrenal replacement therapy for 2 weeks before study.

4. Age, 62. Supresellar cyst diagnosed surgically 30 years before study. Not removed. Gonadal, thyroidal, and adrenal insufficiency for at least 15 years before study. Therapy: depotestosterone and desiccated thyroid. No adrenal replacement therapy for 2 weeks before study.

5. Age, 65. Chromophobe adenoma removed surgically 5 years before study. Gonadal, thyroidal, and adrenal insufficiency. Therapy: methyltestosterone and desiccated thyroid. No adrenal replacement therapy for 6 weeks before study.

6. Age, 35. Chromophobe adenoma. Treated with irradiation on two occasions approximately 8 to 10 years before study. Gonadal, thyroidal, and adrenal insufficiency. Therapy: depotestosterone and desiccated thyroid. No adrenal replacement for 2 weeks before study.

7. Age, 50. Chromophobe adenoma removed 2 months before study. Gonadal, thyroidal, and adrenal insufficiency for at least 2 years before study. Therapy: depotestosterone and desiccated thyroid. No adrenal replacement before study.

8. Age, 60. Plasmacytoma (multiple myeloma) destruction of pituitary with postoperative irradiation of pituitary. Gonadal, thyroidal, and adrenal insufficiency for at least 8 months before study. Therapy: depotestosterone and desiccated thyroid. No adrenal replacement therapy before study.

9. Age, 39. Chromophobe adenoma with gonadal, thyroidal, and adrenal insufficiency of 3 years' duration. Treated with irradiation 15 years before study. Therapy: depotestosterone and desiccated thyroid. No adrenal steroid replacement for 1 week before study.

10. Age, 60. Adrenal insufficiency of 7 years' duration: etiology, idiopathic. No replacement therapy for 2 weeks before study while the patient was maintained on high salt diet (15 to $20 \mathrm{~g}$ daily).

11. Age, 29. Adrenal insufficiency of 6 years' duration: etiology, idiopathic. No replacement therapy for 2 weeks before study while patient was maintained on high salt diet ( 15 to $20 \mathrm{~g}$ daily).

12. Age, 49. Adrenal insufficiency of 11 years' duration; etiology, questionably tuberculous. No replacement therapy for 2 to 5 weeks before study while patient was maintained on high salt diet (15 to $20 \mathrm{~g}$ daily).

13. Age, 39. Adrenal insufficiency of 9 years' duration; etiology, idiopathic. No replacement therapy for 1 week before study while patient was maintained on high salt diet (15 to $20 \mathrm{~g}$ daily).

\section{REFERENCES}

1. Kleeman, C. R., Maxwell, M. H., and Rockney, R. E. Mechanisms of impaired water excretion in adrenal and pituitary insufficiency. 1 . The role of altered glomerular filtration rate and solute excretion. J. clin. Invest. 1958, 37, 1799.

2. Raisz, L. G., McNeely, W. F., Saxon, L., and Rosenbaum, J. D. The effects of cortisone and hydrocortisone on water diuresis and renal function in man. J. clin. Invest. 1957, 36, 767.

3. Welt, L. G. The influence of disease on the renal excretion of water in Essays in Metabolism, L. G. Welt, Ed. Boston, Little, Brown, 1957, p. 299.

4. Nabarro, J. D. N. The adrenal cortex and renal function in Modern Views on the Secretion of Urine, F. R. Winton, Ed. London, Churchill, 1956, p. 148

5. Strauss, M. B. Body Water in Man. Boston, Little, Brown, 1957.

6. Smith, H. W. Salt and water volume receptors: An exercise in physiologic apologetics. Amer. J. Med. 1957, 23, 623.

7. Clarke, A. P. W., Cleghorn, R. A., Ferguson, J. K W., and Fowler, J. L. A. Factors concerned in the circulatory failure of adrenal insufficiency. J. clin. Invest. 1947, 26, 359.

8. Hills, A. G., Chalmers, T. M., Webster, G. D., Jr., and Rosenthal, O. Adrenal cortical regulation of the distribution of water and electrolytes in the human body. J. clin. Invest. 1953, 32, 1236.

9. Martin, M. M. Combined anterior pituitary and neurohypophyseal insufficiency. Studies of body fluid spaces and renal function. $J$. clin. Invest. 1959, 38, 882.

10. Kleeman, C. R., Epstein, F. H., and White, C. The effect of variations of solute excretion and glomerular filtration on water diuresis. J. clin. Invest. 1956, 35, 749.

11. Burston, R. A., and Garrod, O. The variability of the lower glomerular filtration rate in Addison's disease and panhypopituitarism, and the effect of cortisone thereon. Clin. Sci. 1952, 11, 129.

12. Kleeman, C. R., Koplowitz, J., Maxwell, M. H., Cutler, R., and Dowling, J. T. Mechanisms of impaired water excretion in adrenal and pituitary insufficiency. II. Interrelationships of adrenal cortical steroids and antidiuretic hormone in normal subjects and in diabetes insipidus. J. clin. Invest. 1960, 39, 1472.

13. Rosenbaum, J. D., Nelson, W. P., III, Strauss, M. B.. Davis, R. K., and Rossmeisl, E. C. Variation in the diuretic response to ingested water related to 
the renal excretion of solutes. J. clin. Invest. 1953, $32,394$.

14. deWardener, H. E., and Del Greco, F. The influence of solute excretion rate on the production of a hypotonic urine in man. Clin. Sci. 1955, 14, 715.

15. Berliner, R. W., and Davidson, D. G. Production of hypertonic urine in the absence of pituitary antidiuretic hormone. J. clin. Invest. 1957, 36, 1416.

16. Orloff, J., Wagner, H. N., Jr., and Davidson, D. G. The effect of variations in solute excretion and vasopressin dosage on the excretion of water in the dog. J. clin. Invest. 1958, 37, 458.

17. Lamdin, E., Kleeman, C. R., Rubini, M., and Epstein, F. H. Studies on alcohol diuresis. III. The re- sponse to ethyl alcohol in certain disease states characterized by impaired water tolerance. J. clin. Invest. 1956, 35, 386.

18. Kleeman, C. R., Cutler, R. E., and Maxwell, M. H. The effect of intracarotid infusions of cortisol on impaired water diuresis of the adrenalectomized dog. Unpublished observations. Presented at the American Endocrinological Society meeting, Miami Beach, Fla., June 1960.

19. Cutler, R., Kleeman, C. R., Dowling, J. T., and Maxwell, M. H. Physiological studies in a family with nephrogenic (vasopressin-resistant) diabetes insipidus (N.D.I.) (abstract). J. clin. Invest. 1960, 39, 980 . 